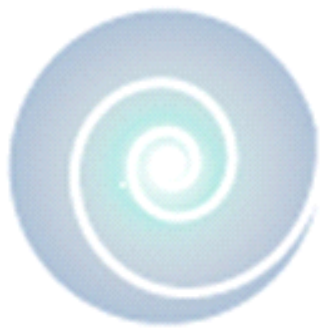

\title{
From the Executive Editor's Perspective ...
}

Welcome to this inaugural issue of the International Journal of Therapeutic Massage and Bodywork: Research, Education, and Practice (IJTMB), a quarterly publication of the Massage Therapy Foundation. The journal strives to provide the massage/bodywork profession and related health science communities with a peer-reviewed scientific forum that is open access for its readership and contributing authors. This first issue, appearing in August 2008, will be followed by a December issue. Beginning in 2009, quarterly issues of the journal will appear in March, June, September, and December.

As suggested by the journal's subtitle, an important assumption underlying this publication is that research provides the foundation for education and training efforts intended to guide the work of practitioners. Against the backdrop of the ongoing emphasis on evidence-informed practice, the journal seeks to advance professional practice reflective of three critical components-specifically, current research findings, relevant client-patient factors, and clinical expertise ${ }^{(1,2)}$. Accordingly, this electronic publication is one of several efforts exemplifying the Massage Therapy Foundation's threefold mission of research, education, and service ${ }^{(3)}$.

Appropriate sectors of the journal's website speak to such standard elements as the journal's nature and rationale; scope of content; governance; author guidelines and stylistic requirements; manuscript submission, review, and publication procedures; ethical guidelines; and copyright issues. Navigation through the website is encouraged for first-time visitors interested in exploring the broad range of features defining this publication. Also, the four additional editorials in this issue provide insights from the vantage points of the journal's editor-in-chief and section editors in the areas of Research, Education, and Practice, therefore completing the intended introduction from the fivemember editorial board.

The peer-reviewed nature of the journal is its sine qua non characteristic ensuring the objectivity expected of any reputable scientific publication. In support of this process, distinguished colleagues comprise the journal's manuscript review board and international advisory council. The subscription-free open-access feature of the journal is consonant with a growing trend in scholarly publishing aimed at disseminating scientific and professional knowledge as extensively and equitably as possible ${ }^{(4)}$. In so doing, the IJTMB attempts to avoid existing economic, geographic, and logistic constraints that otherwise might restrict its availability to interested parties. The mechanism for implementing this electronically-driven open access option is the Open Journal System (OJS) software developed as part of Canada's Public Knowledge Project $^{(5,6)}$. The OJS software also provides for two additional features:

- Reading tools that use an author's keywords to search relevant open-access databases for related resources that are then made available to the reader

- A data supplement file option that an author can use to augment an article by uploading any combination of affiliated audio, video, or PowerPoint presentation files

The Research Section of the journal provides an opportunity for disseminating the results of original scientific inquiry representing any of the methodologic options spanning the complete range of quantitative, qualitative, and integrative studies. The Education Section focuses on noteworthy features of certificate-, license-, and degree-specific programs, as well as on continuing education options as they relate to the following areas: curriculum development; instructional design and delivery; instructional technology; distance learning; and testing/evaluative procedures in both classroom and clinical settings. The Practice Section of the journal represents a venue for the application of scientific findings and clinical expertise to approaches for preventing and treating specific health conditions. Across these three principal sections of the journal, emphasis on translational science is strongly encouraged in an effort to foster a reciprocal "bench-to-bedside and bedside-to-bench" dialogue among colleagues $^{(7,8)}$.

Your input by way of the Commentaries Section is encouraged in three ways: letters to the editor about any aspect of the journal, book reviews, and reactions to published articles (with the prerogative of author rebuttal ensured). For the News/Announcements feature of the journal, we invite readers to submit information pertaining to forthcoming professional conferences, continuing education options, and individual professional accomplishments. This section is not a venue, however, for the commercialization of products or services.

Entries in the IJTMB are governed stylistically and ethically by the publication guidelines of the International Committee of Medical Journal Editors' (ICMJE), 
Uniform Requirements for Manuscripts Submitted to Biomedical Journals ${ }^{(9)}$. Published articles are licensed under the Creative Commons Attribution-Noncommercial-No Derivative Works 3.0 license ${ }^{(10,11)}$. Accordingly, copyright retention by authors, first publication rights for the journal, free use with proper attribution in noncommercial settings, and prohibition of derivative works are all ensured. The journal's publishing firm, Multimed, Inc., provides an article preparation service to prospective authors ${ }^{(12)}$.

Readers are encouraged to join our efforts to make the availability of this journal known as extensively as possible to colleagues, institutions, and the public at large. We invite prospective authors to share their insights and expertise in manuscript submissions that are critically reasoned, well articulated, and reflective of the professional literature pertinent to the issues addressed. The broad scope of the journal accommodates quite well the possibility of diversified contributions that highlight original research and the insights of educators and practitioners. This journal acknowledges the contributions of the various publications already available in the massage, bodywork, and related health science communities. It attempts, nonetheless, to augment those forums for scholarly conversation by way of this new peer-reviewed open-access effort that aims to be inclusive in its readership and contributing authors. In so doing, we hope to respond in meaningful ways to the challenges facing our respective professions.

Again, welcome to the opportunities afforded by this journal as we strive to provide the best possible care to those we serve.

Glenn M. Hymel, EdD, LMT Executive Editor, IJTMB Professor and Chair Department of Psychology Loyola University New Orleans, LA, USA

\section{COMPETING INTERESTS}

The author declares that there are no competing interests.

\section{ACKNOWLEDGMENTS}

The genesis of the International Journal of Therapeutic Massage and Bodywork: Research, Education, and Practice can be traced back to the extensive work of the Massage Therapy Foundation's e-Journal Com- mittee. Members of the committee over the past three years have included John Balletto, Marcus A. Banks (Chair), Amanda Baskwill, Karen Boulanger, Marissa Brooks, Glenn M. Hymel (Immediate Past Chair), Albert Moraska, Alison Pittas, Robin Pollini, Kevin Stranack, Lesley Teitelbaum, and Diana L. Thompson.

\section{REFERENCES}

1. Finch PM. The evidence funnel: highlighting the importance of research literacy in the delivery of evidence informed complementary health care. J Bodywork Mov Ther. 2007;11(1):78-81.

2. Bowen S, Zwi AB. Pathways to "evidence-informed” policy and practice: a framework for action. PLoS Med. 2002;2(7):e166.

3. Massage Therapy Foundation. Mission and History. Massage Therapy Foundation website.http://www.massagetherapyfoundation.org/ mission.html. Updated n.d. Accessed May 22, 2008.

4. Willinsky J. The Access Principle: The Case for Open Access to Research and Scholarship. Cambridge, MA: MIT Press; 2006.

5. Public Knowledge Project. OJS in an Hour: An Introduction to Open Journal Systems. Version 2.2.1.0. Vancouver, BC: University of British Columbia; 2008. http://pkp.sfu.ca/files/ OJSinanHour.pdf. Updated July 15, 2008. Accessed July 16, 2008.

6. Public Knowledge Project (PKP). Home page. PKP website. http://pkp.sfu.ca. Updated n.d. Accessed May 22, 2008.

7. Woolf SH. The meaning of translational research and why it matters. JAMA. 2008;299:211-213.

8. United States, Department of Health and Human Services, National Institutes of Health, Office of Portfolio Analysis and Strategic Initiatives (OPASI). Translational Research. NIH Roadmap for Medical Research website. http://nihroadmap.nih.gov/ clinicalresearch/overview-translational.asp. Updated March 19, 2008. Accessed May 22, 2008.

9. International Committee of Medical Journal Editors (ICMJE). Uniform Requirements for Manuscripts Submitted to Biomedical Journals: Writing and Editing for Biomedical Publication. ICMJE website. http://www.ICMJE.org. Updated October 2007. Accessed May 22, 2008.

10. Creative Commons. Home page. Creative Commons website. http://creativecommons.org. Updated n.d. Accessed May 22, 2008.

11. Creative Commons. Attribution-Noncommercial-No Derivative Works 3.0 Unported. Creative Commons website. http:// creativecommons.org/licenses/by-nc-nd/3.0. Updated n.d. Accessed May 22, 2008.

12. Multimed, Inc. Home page. Multimed website. http:// www.multi-med.com. Updated n.d. Accessed May 22, 2008. 